DOI: 10.17976/jpps/2020.03.05

\title{
РАЗВИТИЕ СЕЛЬСКИХ МЕСТНЫХ СООБЩЕСТВ: ПОТЕНЦИАЛ ПОЛИТИКИ ИДЕНТИЧНОСТИ
}

\author{
Е.В. Морозова, И.В. Мирошниченко, И.С. Семененко
}

МОРОЗОВА Елена Васильевна, доктор философских наук, профессор кафедры государственной политики и государственного управления, Кубанский государственный университет, Краснодар, email: morozova_e@inbox.ru; МИРОШНИЧЕНКО Инна Валерьевна, доктор политических наук, зав. кафедрой государственной политики и государственного управления, Кубанский государственный университет, Краснодар, email: mirinna78@mail.ru; CEMЕНЕНКО Ирина Станиславовна, доктор политических наук, член-корр. РАН, зам. директора по научной работе, Национальный исследовательский институт мировой экономики и международных отношений им. Е.М. Примакова РАН, Москва, email: semenenko@imemo.ru

Е.В. Морозова, И.В. Мирошниченко, И.С. Семененко. Развитие сельских местных сообществ: потенциал политики идентичности. - Полис. Политические исследования. 2020. № 3. С. 56-77. https://doi.org/10.17976/jpps/2020.03.05

Статья подготовлена при финансовой поддержке РФФИ и ЭИСИ, проект № 19-011-31356 “Развитие сельских местных сообществ: потенциал политики идентичности в условиях гетерогенного социально-экономического и социокультурного пространства региона”.

Статья поступила в редакцию: 25.12.2019. Принята к публикации: 04.03.2020

Аннотация. Статья посвящена изучению потенциала политики идентичности как нематериального ресурса развития местных сообществ и обоснованию критериев его оценки. Перспективы перехода к новой парадигме развития в условиях кардинальных изменений в структуре общественных отношений становятся важной составляющей научного дискурса, в свою очередь, резко актуализируя задачу выявления потенциала такой политики. Эти изменения отражаются и в формировании миропорядка, и в появлении новых социальных и культурных размежеваний внутри современных обществ, в том числе в углублении цифрового неравенства и радикальной поляризации социальных пространств развития и территорий неразвития, в становлении новой повестки дня политики развития на разных уровнях политического управления. В зарубежной политической науке в последние годы растет внимание к нематериальным ресурсам и управленческим приоритетам развития негородских территорий, в частности, в контексте так называемых сельских исследований. Авторы статьи обосновывают потребность в продвижении “сельских" (негородских) исследований в российском поле политической науки. Ключевую задачу они видят в выявлении ресурсов развития сельских сообществ, в частности, возможностей и ограничений политики идентичности. По итогам интерпретации результатов проведенного в 2019 г. эмпирического исследования в Краснодарском крае (восемь фокус-групповых и 40 экспертных интервью в восьми сельских поселениях Кубани) определены маркеры локальной идентичности сельских сообществ и разработана матрица ее критериев. Охарактеризована структура и особенности политики идентичности в сельских сообществах, проанализированы такие ее институциональные механизмы, как символическая политика и политика памяти. Сравнительная оценка уровня вовлеченности различных субъектов в развитие сельских территорий и системности связанных со стратегическими приоритетами развития мероприятий позволила выявить три типа политики идентичности - реактивный, проактивный и активный, определить их потенциал в разработке и реализации политики развития российских сельских территорий с учетом их уникального социокультурного и природно-географического ландшафта, неоднородности 
социально-экономического и социокультурного пространства российских регионов и различных институциональных моделей местных сообществ.

Ключевые слова: сельские местные сообщества, негородские территории, сельские исследования, политика развития, нематериальные ресурсы развития, локальная идентичность, сельская идентичность, политика идентичности, маркеры идентичности, Краснодарский край, Россия.

Политика развития находится сегодня в центре научных и общественных дискуссий. Однако ее субъектам и приоритетам уделяется разное и очень неравномерное внимание. В политической науке в последние два десятилетия на первый план вышли городские исследования. Город воспринимается как средоточие технологических прорывов, новейших управленческих практик и эффективных социальных инициатив, способных адаптировать человека к новой социальной реальности. Проблемы мегаполисов как растущих социальных агломераций, средоточия социальных проблем и апробации эффективных путей их решения традиционно привлекают повышенное внимание исследователей. Креативный город рассматривается как пространство с большим потенциалом развития социальной среды, в концепции “умного города" приоритет отдается продвижению технологических инноваций и их использованию в современном политическом управлении. Инновационные кластеры объединяют потенциал разных субъектов развития территорий. Большая плотность сетевых взаимодействий таких субъектов формирует “пространства развития”, в которых утверждаются новые модели организации производства и новые формы социального и потребительского поведения.

\section{СЕЛЬСКОЕ ИЗМЕРЕНИЕ ПОЛИТИКИ РАЗВИТИЯ}

Вне таких “пространств развития” оказываются те, кто в условиях цифрового неравенства не может распознать и эффективно использовать свои особые, уникальные ресурсы, связанные как с развитием традиционных, так и с продвижением альтернативных моделей производства и потребления, с нахождением баланса между “традицией” и “инновацией”. В первую очередь это негородские (сельские) сообщества. До недавнего времени их по умолчанию помещали в колею догоняющего (город) развития. С актуализацией угроз экологической безопасности и формированием экологической идентичности отношение к проблемам и потребностям сельских сообществ стало быстро меняться. Эти изменения во многом предопределяют психологический климат современных обществ: среда обитания человека меняется столь стремительно, что сознание не поспевает за этими изменениями, и личность, проживающая кризис идентичности, стремится к поиску позитивного решения [см. Идентичность... 2017]. Стандартизация современного масскультурного ландшафта Макдоналдса и Диснейленда вызывает растущее отторжение; стремление ощутить и утвердить собственную идентичность обращает человека к устойчивым и традиционно привлекательным образам сельского ландшафта, к ценностям, представляющимся подлинными и непреходящими, к приемлемому темпу жизни, который олицетворяет сельская идентичность. Речь отнюдь не идет об идеализации “сельского уклада" (rurality), но о поисках жизненных ориентиров, альтернативных стандартизированной искусственной среде обитания современного человека. 
В альтернативном интеллектуальному мейнстриму исследовательском поле прорастают и принципиально иные подходы к развитию, поэтому неслучайно “сельские" исследования (rural studies) ${ }^{1}$ в последние 10-15 лет стали занимать все более заметное место в социальных науках [см. Handbook... 2006; Routledge International... 2016]. В политических исследованиях растущее внимание уделяется управленческим подходам и ресурсам развития сельских сообществ как субъектов социально-политических изменений [подробнее см. Семененко 2019b], в экспертном сообществе уже не первый год напрямую ставится вопрос о “новой сельской парадигме развития" [The New Rural Paradigm... 2006]. Это последнее направление получило заметное развитие в странах Северной Европы: здесь активно идут поиски моделей эффективного управления развитием сельских территорий [Svendsen 2004; Cruickshank, Lysgård, Magnussen 2009; Lundgren, Johansson 2017; Nilsson, Lundgren 2018]. Проблемы негородских сообществ занимают заметное место в политическом дискурсе не только западных, но и незападных обществ.

Сельские территории расположены в природно-географическом ландшафте за пределами городских агломераций, они имеют свои источники продовольствия, сельскохозяйственного сырья и природных ресурсов; относительно низкая плотность населения способствует поддержанию "негородского” темпа и образа жизни. В современной политико-управленческой и экономической практике возникла потребность в поиске эффективных моделей развития сельских территорий, которые могли бы способствовать консолидации сообществ граждан, заинтересованных в новом качестве жизни. Это тем более важно потому, что управленческие проблемы не сводятся сегодня к организации эффективного аграрного производства: непосредственно в сельском хозяйстве занята только часть проживающих за пределами города людей. Так, в странах Западной Европы это от 1-2\% (Великобритания, Дания) до 4\% (Испания, Италия, Австрия) занятого населения, при том что в сельской местности в этих странах проживает от 12\% (Дания) до 42\% (Австрия) населения, всего в странах Евросоюза - 24\%2. Поэтому принципиально новая характеристика политики в отношении сельских территорий - это достижение высокого уровня жизни сельского населения за счет нематериальных факторов развития, а именно качества социальной среды и состояния экологии.

В России в сельском хозяйстве занято около 6\% работающего населения, при том что в сельской местности проживает более четверти (26\%) россиян ${ }^{3}$, а в половине субъектов РФ доля сельского населения составляет до трети и даже более (всего - 37,3 млн человек) ${ }^{4}$. Качество жизни здесь остается заметно ниже городского, особенно это касается социальной инфраструктуры.

\footnotetext{
${ }^{1}$ В выходящем уже четверть века авторитетном англоязычном журнале "Journal of Rural Studies" представлены разные области знания - от социологии, политологии и культурологии до социальной психологии, географии и аграрной экономики; в междисциплинарном поле “сельских" исследований формируются новые подходы к пониманию повестки дня политики развития.

2 Данные Всемирного банка. См. The World Bank. Employment in Agriculture 2019. URL: https://data. worldbank.org/indicator/SL.AGR.EMPL.ZS (accessed: 14.03.2020); Rural population. 2018 revision. URL: https://data.worldbank.org/indicator/SP.RUR.TOTL.ZS (accessed 14.03.2020).

${ }^{3}$ Там же.

${ }^{4}$ Данные Федеральной службы государственной статистики на апрель 2019 г. URL: http://www.gks. ru/wps/wcm/connect/rosstat_main/rosstat/ru/statistics/population/demography/\# (accessed 14.03.2020).
} 
Между тем в такой огромной по протяженности стране социальный климат на селе во многом определяет социальный климат в обществе, его продовольственную и экологическую безопасность. Поэтому принципиально важно актуализировать изучение приоритетов и потребностей развития сельских территорий и продвижение этих приоритетов в повестку дня публичной политики.

Широкий спектр исследований сельской идентичности в зарубежной социологии и политологии подтверждает мысль известного российского географа Л.В. Смирнягина, высказанную им в одной из своих последних статей. Опровергая миф о “смерти пространства" в эпоху глобализации, он пишет о том, что революция в средствах связи и транспорта позволила человеку по-иному строить и использовать пространство - более свободно от внешних обстоятельств и более ориентированно на нужды самого человека. Свойства места важны прежде всего для него самого - это удобная среда обитания, историческое наследие, благоустройство местности, дружественный социум с низкой преступностью и благожелательными традициями [Смирнягин 2016].

В политологическом дискурсе тематика сельской идентичности оказалась заметной лакуной, при том что ее изучение важно "не только с теоретической, но и с политико-управленческой точки зрения": без этого “невозможно осуществлять грамотное стратегическое планирование развития сельских территорий”, использовать их внутренние ресурсы [Морозова 2018]. В качестве объяснения такого положения дел можно предположить, гипотетически, что сельская идентичность интерпретируется как атрибут уходящего традиционного общества, исследование которого не будоражит научное воображение политолога. Кроме того, существует подспудная проекция на предмет исследования бытующих в массовом сознании психологических установок по отношению к сельским жителям как “другим” для горожан (“сельпо”, “лапти”, “деревня” и т.п.).

\section{ТЕОРЕТИЧЕСКИЕ ОСНОВАНИЯ И МЕТОДОЛОГИЯ ИССЛЕДОВАНИЯ}

Понимание "сельского" в социальных науках традиционно строится в привязке к природному ландшафту и сугубо на противопоставлении “городскому”. "Сельская идентичность” если и становилась предметом отдельного внимания в идентитарных исследованиях, то в контексте изучения динамики нации и национальной идентичности [см., например, Neal 2009], либо в соотнесении с динамикой этнической, гендерной, классовой и других социальных идентичностей [см. Leach, Pini 2011]. Однако очевидно, что такое противопоставление в контексте дихотомии традиционализма и модернизации, архаики и инноваций не работает в условиях, когда "село не существует автономно от глобальных процессов. Несмотря на свою отдаленность и продолжающийся дефицит определенных ресурсов, оно включено в них, является полноправным субъектом глобальных социальных трансформаций” [Вдали от городов... 2013: 7]. Встраивающаяся в глобальный рынок деревня активно пересматривает свои смыслы и функции. Как отмечают авторы проекта "Вдали от городов: жизнь восточноевропейского села. Деревенские жизненные миры в России, Эстонии и Болгарии”, “в противовес космополитичной, анонимной, подвижной, стрессогенной городской среде, сельская местность представляется территорией покоя, здоровья и отдыха, хранилищем вечных общечеловеческих ценностей и национальной природы и культуры” [см. Никифорова 2013: 165]. 
В содержательном плане понятие "сельского" является результатом социального конструирования, “его олицетворяет захватывающий мир социальных, культурных и моральных ценностей, которые привычно ассоциируются в нашем сознании с пониманием 'сельского', с сельскими пространствами и сельским укладом (rurality)" [Handbook... 2006]. Осмысление сельских реалий как социальных и культурных конструктов открывает путь к преодолению ментальных стереотипов об “отсталой деревне”, с “сельскостью” скорее ассоциируется сегодня экологическая идентичность. Такая идентичность не сводится к природоохранным приоритетам, она утверждается как важная составляющая гражданской идентичности [Идентичность... 2017: 619-626]. В более широком контексте изменения парадигмы общественного развития сохранение целостности и подлинности природного и культурного, рукотворного ландшафтов при формировании современной социальной среды и в густо населенных городских, и в негородских пространствах становится важным ориентиром ответственного развития [подробнее см. Семененко 2019а].

Ключевым теоретическим конструктом данного исследования, интегрирующим территорию, идентичность и ресурсы развития в общую рамку политики развития, является концепт развития местных сообществ. Под местными сообществами понимается "совокупность людей, объединенных устойчивыми формальными и неформальными связями, которые обусловлены совместным проживанием и деятельностью в пределах общей территории" [Лыска 2013: 99]. Согласно данному подходу, сельские местные сообщества следует рассматривать одновременно как субъект, объект и ресурс развития территории, что проявляется в стратегическом выборе исследовательских приоритетов. Работающие в исследовательской парадигме управления изменениями американские и российские ученые [см. Heller 1989; Glenn 1986; McMillan 1996; Филиппов, Авдеева 2000; Филиппов, Авдеева, Лаврова 2013] выделили чувство принадлежности жителей к местному сообществу как один из главнейших признаков самого сообщества. Они интерпретируют чувство сообщества и механизмы его формирования как показатели внутренней способности и готовности к самоорганизации, самоуправлению и саморазвитию. Данный подход предполагает переход от “сервис-клиентских" ствий местного сообщества и органов власти, где среди местного населения преобладают настроения иждивенчества, к партнерским отношениям с широким гражданским участием местных жителей в выработке и реализации публичных решений.

Неэкономические ресурсы инновационного развития государства в целом и его отдельных территорий связаны с производством постматериальных ценностей (творчество, доступность и динамика информационного обмена, гражданская активность, идея общественного блага), которые трансформируют характер публичных взаимодействий различных акторов. Современные исследователи обращают внимание на повышение роли нематериальных ресурсов в развитии территорий. Такие факторы как близость к сырью и рынкам больше не доминируют, новый бизнес идет туда, где привлекательнее качество жизни, в результате появляются "изощренные потребители простран-

\footnotetext{
5 “Сервис-клиентский подход” основан на внедрении практик делового администрирования в систему публичного управления, органы местного самоуправления рассматриваются как агентства по оказанию услуг населению - клиентам.
} 
ства” [Kotkin 2000]. Анализ этих неэкономических реалий может во многом объяснить, почему при сравнимых исходных экономических возможностях в рамках одного политико-правового режима появляются динамично развивающиеся пространства развития и стагнирующие территории неразвития. Такие размежевания наблюдаются на уровне наднациональных политий (ЕС), национальных государств и даже отдельных политико-административных единиц в их составе.

Пространство развития рассматривается авторами как интерсубъективная социальная и политическая реальность, в которой носители разных идентичностей взаимодействуют вокруг реализации согласованных приоритетов развития.

K “сельским исследованиям” в полной мере может быть отнесен вывод, сделанный учеными Института социологии РАН, реализовавшими проект изучения малых городов в социальном пространстве России. Они полагают, что современные трансформации обусловливают сложность развития местных социумов и неопределенность складывающихся в них социальных ситуаций, что предполагает поиск в каждом конкретном случае сочетания различных методологических подходов и методико-инструментальных техник. Эти подходы и техники складываются в рамках междисциплинарных научных исследований, направленных на преодоление дисциплинарной односторонности, связанной с изучением местных сообществ [Малые города... 2019: 11].

Ключевую задачу авторский коллектив настоящего исследования видел в соединении возможностей теоретических подходов политики развития и эмпирических методов изучения социальной реальности для выявления ресурсов развития сельских сообществ, в частности, возможностей и ограничений политики идентичности. Авторы шли по пути интеграции методов политического анализа в изучение социальных процессов, характерных для сельских территорий России. Краснодарский край 6 был выбран для эмпирического исследования прежде всего потому, что в этом регионе ярко, разносторонне и в то же время противоречиво проявляются процессы, характерные для всех негородских территорий России.

В качестве эмпирических объектов выступили муниципальные образования двух уровней: муниципальные районы и отдельные поселения. Отбор объектов полевого исследования (муниципальных образований) проходил двухступенчатым способом. На первом этапе отбирались муниципальные образования (районы) Краснодарского края на основе двух критериев: 1) достигнутого уровня развития местных сообществ по результатам интегральной оценки потенциала и вектора социально-экономического развития, основанной на таксонометрическом методе экономического анализа; 2) пространственного разделения региона на профильные экономические зоны (согласно "Стратегии

\footnotetext{
${ }^{6}$ Бренд региона как “житницы России” имеет объективные основания: Краснодарский край занимает ведущее место по переработке сельскохозяйственной продукции и поставкам продовольствия в промышленные центры страны. Численность постоянного населения Кубани на 1 июня 2019 г. составила 5,65 млн человек, из которых 2,53 млн человек $(44,7 \%)$ - сельские жители. Кубань отличает высокая степень культурно-национального многообразия: здесь проживают представители более 120 этнических общностей, включающих население коренное (старожильческое) и появившееся на Кубани в результате миграционных процессов преимущественно в XX в. Край входит в число российских регионов, наиболее привлекательных для внутренней миграции. Здесь высока предпринимательская активность, жив предпринимательский дух. Жизненные ценности населения отличает устойчивое сочетание традиционализма и инновационности.
} 
социально-экономического развития Краснодарского края до 2030 года"7). В соответствии с указанными критериями первая ступень отбора в выборке включала четыре муниципальных образования:

- Тимашевский район (развивающиеся местные сообщества с повышающимися темпами экономического роста в Центральной экономической зоне);

- Темрюкский район (развивающиеся местные сообщества с понижающимися темпами роста в Черноморской экономической зоне);

- Крыловской район (регрессирующие местные сообщества с замедляющимися темпами регресса в Северной экономической зоне);

- Апшеронский район (регрессирующие местные сообщества с увеличивающимися темпами регресса в Предгорной экономической зоне).

Второй ступенью отбора было определение внутри муниципального образования (района) поселений, имеющих полярные показатели социальноэкономического развития. Метод бинарных сравнений использовался в каждом из муниципальных районов, объектами сравнения становились сельские поселения, имеющие отчасти сходные стартовые условия, но занимающие противоположные позиции на шкале социально-экономического благополучия. Наряду с данными социально-экономической статистики авторы использовали оценки экспертов, которым предлагалось назвать самое благополучное и самое неблагополучное сельское поселение в районе.

В рамках качественного исследования авторы сосредоточили внимание на решении исследовательского вопроса: каково влияние ресурсных характеристик локальной идентичности и политики идентичности на развитие сельских территорий?

Методика эмпирического исследования локальной идентичности и политики идентичности в сельских поселениях основывалась на совокупности таких методик социологического анализа, как фокус-групповая дискуссия, экспертный опрос в форме полуструктурированных интервью и последующей политологической интерпретации результатов. Нас интересовала не только степень сформированности локальной идентичности, но и степень структурированности политики идентичности, роль различных субъектов в ее продвижении, влияние последней на развитие сельских поселений, на образы будущего. Всего в муниципальных районах было проведено 8 фокус-групповых интервью. В социологический инструментарий фокус-группы была интегрирована методика проективного рисунка "Моя станица в будущем" для выявления коллективного субъективного образа “будущего” сельской местности в глазах ее жителей по схеме "что было - что будет". Экспертный опрос позволил верифицировать данные, полученные в результате фокус-групповых интервью, и получить экспертное мнение относительно эффективности политики идентичности на локальном уровне. В каждом муниципальном районе было опрошено по 10 экспертов (всего 40 человек); в качестве экспертов выступили руководители органов местного самоуправления, работники учреждений культуры (музеи, библиотеки, дома культуры), учителя истории, обществознания и кубановедения, представители муниципальных СМИ и местного бизнеса. Эмпирические данные (транскрипты), полученные в результате

\footnotetext{
${ }^{7}$ См. Закон Краснодарского края “О стратегии социально-экономического развития Краснодарского края до 2030 года” от 11.12.2018. URL: https://economy.krasnodar.ru/strategic-planning/files/Strategiia_2030. pdf (accessed 14.03.2020).
} 
фокус-групповых дискуссий и экспертного опроса, были проанализированы и интерпретированы на основе качественной стратегии с использованием методики бинарных сравнений ${ }^{8}$, позволяющих классифицировать локальные идентичности и найти объяснения взаимосвязи и взаимовлияния политики идентичности и векторов развития сельских поселений.

\section{КОМПОЗИТНАЯ МОДЕЛЬ И МАТРИЦА ЛОКАЛЬНОЙ ИДЕНТИЧНОСТИ}

Анализ данных, полученных авторами в рамках полевого исследования, позволил выделить типичные маркеры локальной идентичности, присутствующие в том или ином объеме и соотношении в исследуемых локальных сообществах, и на этом основании оценить нематериальные ресурсы их развития, качество социального капитала сообщества.

По результатам анализа и интерпретации данных авторы предложили композитную модель ${ }^{9}$ идентичности локальных сообществ, содержащую набор следующих типичных маркеров:

- малая Родина - место рождения ("Теплое сердие, дорогое место, куда возврашаешься снова и снова", “Место, где родился, вырос, где твои корни”; "Желание остаться здесь, оно никогда не покидает нас; где бы ни были, мы все равно возвращаемся сюда");

- особенности ландшафта и климата ("Здесь море, рыбалка, вино вкусное, тепло, зимы мягкие”; “Не зря мы говорим, что здесь не три, а то и пять морей: море солнца, море ульбок, море вина"; "Унас есть там поле большое... и вот белая круча, ее отсюда видно, если будете ехать; вот для меня, я уже 15 лет живу, и вот красиво, не надоедает это; вот выходишь и думаешь, какая природа красивая”);

- экономическая специализация и уровень социально-экономического развития ("Принциииальное отличие, наверное, все-таки наши октябрьские сажениы; они известны не только по району, но и по всему краю; потому что в каждый двор можно зайти, и там будут розы, декоративные растения, и такой перечень, что мы и сами не знаем, что это такое у соседей, ходим и спрашиваем”);

- реальные или приписываемые черты коллективного поведения (“Отзывчивые люди, которые рады всегда принять гостей”; “Можно даже детей спокойно отпустить погулять, это очень много значит”; “Люди здесь очень хорошие, добрые, отзывчивые; нет зависти, люди адекватные, все друг друга знаем, здороваемся");

- исторические события, значимые люди ("История, история настолько богатейшая; вот, здесь прошли ну все, кто когда-либо касался России”; “Сохранение традиций казачьего быта, это проведение свадеб, встречи ребенка - это обязательно чтится");

- локальная мифология, структура которой включает такие значимые смысловые конструкты, как миф основания, миф о культурном герое, миф

\footnotetext{
${ }^{8}$ Были определены следующие объекты бинарных сравнений: Апшеронский район - станицы Кубанская и Куринская, Крыловской район - станицы Октябрьская и Кугоейская, Темрюкский район - станицы Голубицкая и Курчанская, Тимашевский район - станицы Медведовская и хутор Беднягин.

${ }^{9}$ Авторы решили назвать модель композитной, заимствовав термин из естественных наук. Композитом называется неоднородный сплошной материал, состоящий из двух и более компонентов, среди которых выделяются армирующие элементы, обеспечивающие необходимые характеристики материала. Введение в политологический текст данной метафоры представляется вполне оправданным ввиду сущностной близости характеристик и является распространенной в социально-гуманитарных науках практикой.
} 
о “золотом веке” советского времени (“Не зря мы говорим, что здесь не три, а то и пять морей...”; “Синеговские сады - почему называются так? В память об одной из первых казачьих семей, основателей станиць”; “От Ростова до Тихорецка все поезда останавливались, когда заправляли водой, потому что самая чистая вода была; на перроне бизнес процветал в то время, так как много было поездов, все останавливались”).

При конструировании локальной идентичности актуализируется один из ее маркеров, который выделяется как доминирующий, тогда как остальным маркерам приписываются вспомогательные и/или латентные функции. В ряду доминирующих маркеров идентичности местных сообществ в исследуемых сельских поселениях Краснодарского края были выделены:

- экономическая специализация (станица Октябрьская Крыловского района, станица Голубицкая Темрюкского района);

- исторические события и факты (станица Куринская Апшеронского района, хутор Беднягин Тимашевского района);

- природно-ландшафтные ресурсы и экология (станица Кугоейская Крыловского района, станица Курчанская Темрюкского района);

- особый характер коллективного поведения (станица Кубанская Апшеронского района);

- фрагментация локального социального пространства (станица Медведовская Тимашевского района).

Для построения матрицы локальной идентичности, помимо критерия доминантного маркера, мы использовали критерии темпоральной ориентации и вовлеченности жителей. Их выбор обусловлен ключевой задачей исследования - выявить взаимосвязь и взаимовлияние политики идентичности и политики развития. Локальную идентичность в различных станицах отличает разная темпоральная ориентация. Там, где она является перспективной, участники фокус-групповых интервью и эксперты много и охотно говорили о планах на будущее, конкретных проектах развития поселений, связывали с ними будущее своих детей. Проективные рисунки в этом случае отличаются как выбором яркой цветовой гаммы, так и изображением разделяемого общего образа будущего (например, в станице Октябрьской, где реализуется проект строительства большого парка со спортивным комплексом, почти все участники этот комплекс изобразили).

В случае ретроспективной ориентации локальной идентичности чувство привязанности к своей станице связано с переживанием утраченного прошлого, прежде всего советского: “В колхозе у нас 'Октябрь', я вам сейчас точно скажу, у нас было водителей 110 человек. На машинах ездили в Тюмень и везде, были работы людям. Представляете? 110 водителей! Дальше. Взять элеватор. Крупнейший у нас элеватор, людей сколько там работало. Это как я, ну как, молодой специалист приехала, видела это все... И все это (на всех хуторах было) постепенно загнивало, уничтожалось. Все...”. “Я с детства здесь. Мои родители приехали сюда из Ростова, а вообще их привезли еще деды, когда лесокомбинаты были. С Ивановской, Владимирской области они приезжсали. Потому что, когда лесокомбинаты работали, здесь жсе и квартиры выдавали, и работа была, гремело все. Это сейчас все затихло”. Люди старшего возраста с ностальгией вспоминают о работавших предприятиях и домах культуры, о социальных гарантиях. Эти нотки были достаточно сильны 
и в станицах с перспективной темпоральной ориентацией ${ }^{10}$. Символической демонстрацией отсутствия перспективы в одной из станиц стал рисунок “Моя станица через 10 лет”, на котором автор изобразил пустыню и верблюда.

Критерий вовлеченности населения в процессы развития необходим как важный показатель субъектности местного сообщества. Последняя проявляется в способности артикулировать, аккумулировать свои интересы и находить институциональные решения проблем территории. Мы выделили такие виды вовлеченности, как позитивная, абсентеистская и смешанная. На основе интерпретации результатов эмпирического исследования и комбинаций трех вышеназванных критериев авторами предложена матрица локальной идентичности.

Таблица (Table)

Критериальная матрица локальной идентичности

Criteria Matrix of Local Identity

\begin{tabular}{|l|l|l|l|}
\hline $\begin{array}{c}\text { Станица (показатели ее } \\
\text { социально-экономического } \\
\text { развития в районе) }\end{array}$ & Доминантный маркер & $\begin{array}{c}\text { Темпоральная } \\
\text { ориентация }\end{array}$ & Вовлеченность \\
\hline $\begin{array}{l}\text { Октябрьская, Крыловский } \\
\text { район (высокие) }\end{array}$ & $\begin{array}{l}\text { Экономическая } \\
\text { специализация }\end{array}$ & Перспективная & Позитивная \\
\hline $\begin{array}{l}\text { Кугоейская, Крыловский } \\
\text { район (низкие) }\end{array}$ & $\begin{array}{l}\text { Природно- } \\
\text { ландшафтные ресурсы } \\
\text { и экология }\end{array}$ & Ретроспективная & Абсентеистская \\
\hline $\begin{array}{l}\text { Куринская, Апшеронский } \\
\text { раион (низкие) }\end{array}$ & $\begin{array}{l}\text { Исторические } \\
\text { события и факты }\end{array}$ & Ретроспективная & Позитивная \\
\hline $\begin{array}{l}\text { Кубанская, Апшеронский } \\
\text { район (высокие) }\end{array}$ & $\begin{array}{l}\text { Коллективное } \\
\text { поведение }\end{array}$ & Перспективная & Позитивная \\
\hline $\begin{array}{l}\text { Медведовская, Тимашевский } \\
\text { район (высокие) }\end{array}$ & $\begin{array}{l}\text { Фрагментация } \\
\text { локального } \\
\text { социального } \\
\text { пространства }\end{array}$ & Ретроспективная & Смешанная \\
\hline $\begin{array}{l}\text { Беднягин (Кубанец), } \\
\text { Тимашевский район (низкие) }\end{array}$ & $\begin{array}{l}\text { Исторические } \\
\text { события и факты }\end{array}$ & Ретроспективная & Смешанная \\
\hline $\begin{array}{l}\text { Голубицкая, Темрюкский } \\
\text { район (высокие) }\end{array}$ & $\begin{array}{l}\text { Экономическая } \\
\text { специализация }\end{array}$ & Перспективная & Позитивная \\
\hline $\begin{array}{l}\text { Курчанская, Темрюкский } \\
\text { раион (низкие) }\end{array}$ & $\begin{array}{l}\text { Природно- } \\
\text { ландшафтные ресурсы } \\
\text { и экология }\end{array}$ & Ретроспективная & Смешанная \\
\hline
\end{tabular}

\section{ПОЛИТИКА ИДЕНТИЧНОСТИ В СЕЛЬСКОМ ИЗМЕРЕНИИ}

Под политикой идентичности в контексте данного исследования мы понимаем комплекс мер, проводимых различными субъектами политики и направленных на формирование чувства принадлежности к местному сообществу, готовности содействовать его развитию. Политологическая интерпретация эмпирических данных позволила создать объяснительную модель политики идентичности на локальном уровне, включающую субъекты и институциональные механизмы интеграции политики идентичности в проекты развития сельских территорий.

\footnotetext{
${ }^{10}$ На тотальную ретроспективную ориентацию обратила внимание социолог О. Бредникова, которая заметила, какие именно явления “сельского уклада" понимаются сегодня как “тени” минувшего. Например, ориентация в пространстве сопровождается метками “бывший детский сад”, “бывший клуб” и т.д. "Будущее же для сельских жителей существует лишь за пределами деревни” [Вдали от городов... 2013: 48].
} 
Исследуемые сельские поселения демонстрируют модели сетевого взаимодействия субъектов местных сообществ, вовлекаемых в политику идентичности на основе разнообразных институциональных механизмов. Результаты эмпирического исследования показали, что в станицах существуют различные модели политики идентичности, основанные на актуализации нескольких институциональных механизмов. Например, в станице Октябрьской Крыловского района позитивная локальная идентичность местного сообщества с ярко выраженной субъектной позицией бизнес-элиты и предпринимательских структур является устойчивым ресурсом развития данной территории. Пример станицы Куринской Апшеронского района показал, что местное сообщество может быть интегрированным, иметь опыт вовлечения разных групп населения в политику памяти, но при этом ярко выраженную ретроспективную ориентацию, не позволяющую выявить наличные ресурсы и осмыслить перспективы развития. Напротив, пример станицы Кубанской того же района представляет собой, по сути, нормативную модель местного сообщества с позитивно окрашенной четко выраженной локальной идентичностью в сочетании с установкой местных жителей на совместную социальнопреобразовательную активность.

Основными факторами, которые влияют на полноту субъектности органов местного самоуправления (советов депутатов и глав администрации станиц), являются инициируемые “сверху” неоднократное административно-территориальное переподчинение населенных пунктов и непродуманная кадровая политика. Нередки ситуации, когда “сверху” главами поселений назначаются управленцы, слабо связанные или вообще не связанные с территориями в одной из станиц таких назвали “легионерами”. “Легионеры” формируют клиентелу руководителя района и ставят во главу угла своей деятельности лояльность патрону, а отнюдь не потребности местного сообщества.

О том, какую позитивную роль может играть фактор лидерства и преемственности, красноречиво говорит опыт станицы Кубанской Апшеронского района. Глава поселения, Иван Михайлович Триполец, занимает свой пост с 2002 г., четыре раза выигрывал выборы. Его команда, обеспечивая успешное развитие станицы, ориентируется на будушее, сохраняет преемственность и использует опыт предыдущих поколений. Показательны примеры личных жизненных траекторий “старожилов”" . Емельянов Николай Иванович, 82-х лет, проработав главой сельской администрации более 25 лет, возглавил Совет ветеранов Кубанского сельского поселения: “он знает все ходы-выходы в Краснодарском крае, все учреждения”. Ковтун Анатолий Иванович, 72-х лет, “...имея опыт народного депутата Верховного Совета Киргизии в советские годы, ...я не мог не вести активный образ жизни: 3 срока, то есть 15 лет был председателем совета Кубанского сельского поселения. В настоящее время не желаю оставаться в стороне, продолжаю работать...”.

\footnotetext{
11 Такие случаи - это отнюдь не уникальный ресурс изучаемого нами региона. Важность фактора лидерства подчеркивает пример возвращения к жизни уральской деревни Малый Турыш. Выпускница МГУ Гузель Санжапова вернулась в деревню, где живет ее семья, смогла развить успешный бизнес, реализовать краудфандинговый проект в его поддержку и теперь занимается сооружением общественного центра. В одном из интервью Г. Санжапова сказала: “Если раньше я считала, что мой бизнес про мед, то сейчас понимаю - нет, он про развитие территории" (Санжапова Г. 2019. Как мед с ягодами помогает развивать деревню. - РБК-Бизнес. 23.12. URL: https://www.rbc.ru/business/23/12/2019/5dfcce 759a7947b97de75778 (accessed 14.03.2020)).
} 
Бизнес реализует субъектную позицию как в партнерстве с органами местного самоуправления (в станицах Октябрьской, Куринской, Кубанской), так и дистанцируясь от них (станица Медведовская). Основанием локальной идентичности в станице Октябрьской является причастность местного населения, в том числе и активных предпринимателей, к разведению и продаже саженцев плодово-ягодных и декоративных растений, к проекту “Октябрьские саженцы”. В рамках этого проекта происходит информационный и материальный обмен “новинками” растениеводства, продвижение продукции в сетевых платформах, проводятся мастер-классы по ландшафтному дизайну декоративных растений, продвижение продукции в сетевых платформах и т.д. Практически все семьи, проживающие на территории этой станицы, вовлечены в тепличную и питомниководческую деятельность, которая в структуре местной экономики приобретает формы индивидуального предпринимательства или личных подсобных хозяйств. Сообщество производителей саженцев, по словам участников фокус-группы, продвигает “октябрьские саженцы” не только в пределах района, но по всему краю. Экономическая специализация прослеживается в образе жизни, природном и социокультурном ландшафте сельского поселения. Станица Октябрьская “утопает” в розах и декоративных растениях, практически у каждого домовладения установлены стационарные вывески с перечнем предлагаемых саженцев. Дни станицы сопровождаются конкурсами ландшафтного дизайна домовладений.

Активными субъектами политики идентичности выступают общественные организации и движения самой разной направленности: от традиционных советов ветеранов и квартальных комитетов до уникальных организаций, таких как сообщества потомков первых переселенцев в одной из станиц. Они не только участвуют в общестаничных акциях (праздники, субботники и др.), но и ведут свою инициативную деятельность, включающую различные механизмы формирования локальной идентичности. Примером может служить поисковый отряд "Высота" в станице Куринской. Благодаря работе сельских поисковиков около двух тысяч павших в окрестностях станицы советских воинов были похоронены с почестями, более 800 семей узнали о месте гибели своих близких.

Структура процесса формирования локальной идентичности была бы неполной без церкви как актора этого процесса. В изучаемых станицах мы наблюдали разные ситуации взаимодействия органов местного самоуправления с настоятелями сельских приходов, от полной включенности батюшки во все мероприятия станичной общественности до его отстраненности. Наверное, самый впечатляющий пример - это публичное пространство станицы Кубанской, организованное вокруг Свято-Троицкой церкви. Жители с гордостью сообщают, что храм, возведенный в 1874 г., практически сразу после окончания военных действий русско-турецкой войны, является старейшим в предгорной зоне края. Его настоятель, отец Николай, признанный селянами моральный авторитет, всегда в центре общественных событий. В публичном пространстве вокруг храма находятся сквер, школа (располагается в сохраняемом и ухоженном помещении казачьей школы начала XX в.), футбольное поле и спортивные площадки с самым современным покрытием.

Но все же не будет преувеличением сказать, что основными субъектами, “коренниками” политики идентичности выступают культурно-просветительские сети, объединяющие школы и учреждения культуры - дома культуры, 
музеи, библиотеки. В разных станицах их материально-техническая база отличается, но преданность делу и самоотверженный труд работников сферы культуры и образования, сохраняющих и передающих культурные ценности и традиции, показательны везде. В станице Кубанской библиотека получает грантовую поддержку, располагается в хорошем благоустроенном здании, а в станице Медведовской она находится в неотапливаемом Доме культуры - но в обоих случаях библиотекари действительно являются хранителями локальной идентичности. Правда, в первом случае библиотека располагает оцифрованными материалами об основателях станицы и династиях первых поселенцев, а во втором - коллекциями уже пожелтевших от времени газетных вырезок и альбомов.

Из существующих в степных и предгорных станицах музеев только один, музей Ю.В. Кондратюка в станице Октябрьской, имеет официальный статус и небольшой штат сотрудников. В основном музейная деятельность представлена школьными музеями, экспозиции которых отражают две главных темы: казачество и казачий быт и события Великой Отечественной войны. В школе станицы Куринской музей “живой”, пополняется свежими экспонатами, школьники считают за честь быть общественными экскурсоводами. А школьный музей в станице Кугоейской, хоть и имеет ряд ценных исторических экспонатов, производит удручающее впечатление. Основные стенды выполнены в конце 1960-х - начале 1970-х годов, судя по стилистике графического дизайна и идеологемам в тексте. По состоянию и активности музея можно судить о том, насколько важны ресурсы политики памяти в формировании локальной идентичности.

В ходе исследования была обоснована типология политик идентичности на локальном уровне (реактивная, проактивная и активная), характеризующиеся степенью вовлеченности различных субъектов в развитие сельских территорий и системностью мероприятий, связанных со стратегическими приоритетами развития. Реактивная политика идентичности характеризуется отсутствием выработанной стратегии развития местных сообществ и ситуативным включением отдельных субъектов политики идентичности в мероприятия, инициированные извне и способствующие актуализации локальной идентичности. Проактивная политика идентичности представляет собой набор разрозненных мер, основанных на включенности ряда субъектов и институциональных механизмов, но не имеющих общей стратегии и инклюзии в проекты развития территорий. Активная политика идентичности включает в себя восприятие субъектами и местным сообществом локальной идентичности как ценности и ресурса развития, имеется стратегия и ее институциональное воплощение; политика идентичности дифференцирована по направлениям и является неотъемлемым компонентом разработки и реализации стратегии развития муниципальных образований.

Косвенным показателем развития/неразвития сельских поселений является численность детей и молодежи в структуре населения. В развивающихся сельских поселениях школы вынуждены переходить на двухсменную работу, нанимать новых учителей, увеличивать количество “параллельных" классов. И, напротив, в депрессивной станице в школе, рассчитанной на 420 человек, учится 160. Мотивация молодежи, оставшейся после получения образования в родной станице, разная. В целом наши наблюдения совпадают с вывода- 
ми питерских социологов, сделанными по итогам исследования локальной идентичности сельской молодежи в Ленинградской области: существуют три типа предпосылок, конституирующих локальные идентичности молодежи рациональный выбор, биографическая связность и социальная укорененность [Nartova, Krupets 2019].

Молодые люди составляли четверть участников фокус-групп, и они достаточно четко формулировали плюсы и минусы своей жизни на селе. Минусы: плохо с работой, многие кормильцы семьи работают вахтовым методом в Сибири или ищут работу в ближних городах края; недостаточно развита досуговая инфраструктура. Плюсы: включенность в систему родственных и соседских связей, которая всегда позволяет “оставаться на плаву”, чистая окружающая среда и безопасность, здоровая морально-психологическая среда для воспитания детей.

\section{СИМВОЛИЧЕСКАЯ ПОЛИТИКА И ПОЛИТИКА ПАМЯТИ В КУБАНСКИХ СТАНИЦАХ}

Основными институциональными механизмами политики идентичности на локальном уровне являются символическая политика и политика памяти. Значимые в методологическом плане выводы о роли символической политики в конструировании идентичности были сформулированы в работах О.Ю. Малиновой, Г.В. Пушкаревой [Малинова 2017; Пушкарева 2017]. Авторы разделяют “широкое" 12 понимание символической политики, ориентирующее на изучение совокупности действий коллективных акторов и механизмов, обусловливающих результаты такового взаимодействия [Малинова 2017: 659].

Символическая политика формирует локальную идентичность, используя символы разного происхождения, имеющие смыслообразующее значение для конкретного территориального сообщества. В качестве официальных символов в наших станицах используются гербы. К примеру, герб станицы Куринской вобрал в себя все значимые для станичников символы: зелень кавказского предгорья, синеву реки, знак Куринского казачьего полка, основавшего станицу, колесо паровоза (значительная часть населения работает на железной дороге).

Интересны и неофициальные символы, о значении которых говорили респонденты. Таковыми могут быть: архитектурные памятники (администрация Медведовского сельского поселения располагается в красивом здании бывшей женской казачьей школы); публичные пространства ("Военная горка" в Темрюкском районе); места паломничества (святой источник Илии-пророка в окрестностях станицы Куринской); природные символы (розы в станице Октябрьской, Белые скалы в станице Куринской).

Особую роль в политике идентичности играют персонализированные символы-идентификаторы. Для станицы Октябрьской это ученый Юрий Васильевич Кондратюк, один из пионеров разработки основ космонавтики, имя которого по праву стоит в одном ряду с именами таких выдающихся ученых, как К.Э. Циолковский, Н.И. Кибальчич, Ф.А. Цандер, С.П. Королев. Ю.В. Кондратюк именно в период своей работы на Кубани рассчитал оптимальную траекторию полета к Луне. Эти расчеты были использованы NASA

\footnotetext{
12 “Узкое” понимание символической политики предполагает целенаправленное конструирование смыслов элитами в расчете на манипуляцию сознанием масс.
} 
в лунной программе "Аполлон”. Предложенная ученым траектория была впоследствии названа “трассой Кондратюка”. А на своего потенциального персонализированного идентификатора, Виталия Мутко, уроженца станицы Куринской, люди в обиде: не желает государственный муж знаться с представителями своей “малой Родины”, даже награду не принял (“бывший министр спорта Мутко у нас проживал. Наш, куринский. В сейфе до сих пор лежит лента почетного гражданина Куринской”).

Большую роль в символической политике играет увековечивание героев Великой Отечественной войны и героев труда, присвоение их имен местным школам. Важен тот факт, что речь идет о героях, имеющих непосредственное отношение к конкретному сельскому поселению. В Октябрьской, к примеру, одна из школ носит имя знаменитого комбайнера, и благодаря его примеру у детей воспитывается уважение к сельскому труду.

Политика памяти является инструментом консолидации местного сообщества на всех его поколенческих и иных социальных уровнях. Зачастую именно на поле прошлого выстраиваются образы будущего. Авторы использовали концепт коллективной (исторической) памяти, разработанный французским философом и социальным психологом М. Хальбваксом, основная идея которого заключается в том, что носитель всякой коллективной памяти - это "группа, ограниченная в пространстве и во времени" [Хальбвакс 2005]. В нашем исследовании это территориальная группа - жители сельского поселения.

Политика памяти тесно связана с мифами основания. Все станицы, вошедшие в круг наших исследовательских интересов, были основаны казаками. Мифы основания поддерживаются топонимикой: Куринская получила имя по казачьему полку, хутор Беднягин основан казачьим полковником Беднягиным, Синеговские сады в окрестностях Куринской тоже напоминают о человеке, который их заложил. Материализованными следами мифа основания являются хаты первых переселенцев, сохраняемые в ряде станиц, и поразивший нас кованый сундук первого переселенца, сохраняемый как важный символ в администрации Кубанского сельского поселения Апшеронского района. Большую роль в сохранении исторической памяти играют казачьи общества, действующие в станицах.

Особое место в политике памяти занимает сохранение памяти о Великой Отечественной войне. Интегрирующим основанием для локальной идентичности местных жителей станицы Куринской стала идентификация с событиями Великой Отечественной войны, в период которой на территории сельского поселения шли тяжелые бои. Все символические места, большинство названий географических объектов и улиц, а также ключевые мероприятия связаны с оборонительными боями осени 1942 г. Администрация сельского поселения, учителя и ученики, местный поисковый отряд, казачество станицы вовлечены в деятельность по поиску и захоронению погибших солдат, уходу за памятниками, организуют краеведческие экспедиции по местам боев и мероприятия памятных дат с привлечением близких и родственников участников военных действий. Инициатором и идейным вдохновителем местного патриотического движения стала Елена Павловна Георгиевская, бывший учитель. Она не только содержательно выстроила концепцию музея поселения, но и наполнила его экспонатами и “живыми” историями людей того времени, отзывами их потомков. 
В то же время такие исторические события прошлого века, как Первая мировая война, революция 1917 г. и гражданская война, не отражены в исторической памяти населения сколько-нибудь значимыми метками. Это удивительно, потому что население станиц, казачье в своей основе, являлось активным участником данных событий. Всего в Первую мировую было мобилизовано 110 тыс. казаков Кубанского казачьего войска. Гражданская война на Кубани, по оценкам историков, продолжалась до 1922 г. и сопровождалась необычайной жестокостью братоубийственного противоборства. Одна из изучаемых в проекте станиц, Медведовская, в период голода 1932-1933 г. была занесена на так называемую черную доску, блокирована войсками за "саботаж хлебозаготовок”. Органами ОГПУ с ноября 1932 по март 1933 гг. было арестовано 1013 человек, из них расстреляно 158 человек. В январе 1933 г. оставшиеся в живых станичники, более 4 тыс. человек, были в полном составе выселены в северные районы СССР. В оставленные дома привезли в организованном порядке военнослужащих из других областей страны. Потомков тех, выселенных, семей в станице сейчас проживает немного. Этот трагический эпизод практически не зафиксирован как значимый в памяти наших собеседников, на прямой вопрос о голоде 1932-1933 гг. и выселении станицы респонденты отвечали неохотно мол, давно это было и быльем поросло. И даже текст на скромном обелиске в память тех событий мало что говорит непосвященному человеку: "В память о павших в 30-е годы 20 века православных казаках станицы Медведовской”. Такие глубинные разрывы исторической памяти можно объяснить и нежеланием осмысливать "неудобные" факты истории, и влиянием существующих в современном информационном поле тематических приоритетов на публичный дискурс и на восприятие людьми исторического прошлого.

\section{СЕЛЬСКИЕ СООБЩЕСТВА: КТО ЗДЕСЬ ДРУГОЙ/ЧУЖОЙ?}

Город как Другой по отношению к селу традиционно рассматривался и в научной литературе, и в массовой культуре как ключевой маркер сельской идентичности. Но и само “село” позиционирует себя как Другой по отношению к городу, отстаивает свою особость в рамках “борьбы за идентичность”. "Безусловно, граница между городом и деревней производится двусторонне. Существует своего рода диалог, в ходе которого вырабатываются конвенциональные социальные значения и смыслы, приписываемые городу и деревне" [Вдали от городов... 2013: 29]. Однако такое противополагание "города" "селу" - это наследие эпохи урбанизации, которая еще несколько десятилетий назад трактовалась в социальных науках как линейный и однонаправленный процесс вытеснения сельских реалий городскими. Сегодня многие работающие в этом поле исследователи сельских реалий критикуют такое противопоставление за бессодержательность в современном контексте информационного общества и новых сетевых пространств, в которых стираются “старые” границы и размежевания и появляются новые [Woods 2011; Dymitrow 2018].

Наше эмпирическое исследование показало, что роль Других/Чужих в глазах сельских жителей отводится отнюдь не горожанам. Мы столкнулись с несколькими вариантами актуализации оппозиции “мы - они”, имеющими разнообразные основания. Для жителей станицы Октябрьской, чья идентичность “сцементирована” общей предпринимательской деятельностью, чужими являются производители саженцев из Крыма, которые “перебивают 
товар саженистов иенами” и предлагаемым разнообразным и в большом объеме ассортиментом. Для станицы Куринской - это жители экологического поселения, обосновавшиеся в горах недалеко от станицы ( “...ux там все больше и больше становится; круглые дома строят; жкивут очень обособленно..."; "Первоначально, они хотели влезть в жизнь поселка; вешали объявления, что мы вам покажем, как нужно пить лечебный чай и как надо питаться сырыми грибами; мы просто сотрудников ФСБ вызвали и все...”). Удивительную ситуацию мы наблюдали в станице Медведовской, жители которой в советское время работали в двух крупных и успешных совхозах. Совхозов давно уже нет, а идентификация двух частей станицы с тем прежним размежеванием (и чувство конкуренции, а иногда и зависти) остается.

Отдельный вопрос - отношение к инокультурным мигрантам. В Октябрьской мы столкнулись с ситуацией взаимного неприятия и высокого уровня конфликтогенности в отношениях между местным населением и цыганской общиной ("Ну те, кто давно жсивет, не очень довольны цыганами. Они ведут себя не очень хорошо: ходят, попрошайничают по дворам, могут открыть калитку и пройти в дом”; “не работают, а ведут себя вообще вызывающе; вот, допустим, придут в храм, я сам наблюдал, уже батюшка не выдержсивет, когда приносят святить паски ${ }^{13}$ там или фрукты, овощи: они мешками приносят и ведут себя вызывающе, разговаривают на своем языке, перебивают”). Противоположная ситуация в станице Кубанской: в структуре многонационального населения около $30 \%$ - это представители мусульманской диаспоры, которая также неоднородна по своему составу (турки-месхетинцы, курды, езиды, хемшилы, азербайджанцы и др.). Миграционные потоки были обусловлены потребностью станицы в сезонных рабочих, которые привлекались к сельскохозяйственной деятельности предприятий станицы: “Здесь работали, потом семьи привезли, потом родственники, естественно, поехали”, “...народ был гостеприимный; человек переехал - ему и теленка отдали, молоко... все, что тебе надо, даст, кирпич привезут, вот такое население здесь... и вот мы пристроились, здесь и жсивем”. “Обязательно проходит в станице ...фестиваль национальных культур”. “Во время фестиваля каждая нация представляет свои блюда и проходит дегустация, в последнее время стали проводить дополнительно еще конкурсы того же сала”. “Кто знает, что в Кубанской проводится день станицы, со всего района люди стекаются сюда”. Иными словами, в Кубанской реализуется на практике модель ответственного развития, в которой моральные ценности, мотивация команды администрации и гражданская ответственность жителей являются неотъемлемыми компонентами управленческих практик.

\section{ЗАКЛЮЧЕНИЕ}

Очевидно, что включение в политическую повестку дня особых интересов сельских жителей является важной научной и политической задачей. Политическая наука в России может способствовать ее решению: необходимо преодолеть “урбаноцентричный” подход, актуализировать сами “сельские” исследования и сформировать системное видение проблем негородского развития, их политического, управленческого и ценностного измерений. Такой результат может быть достигнут путем использования методологических подходов разных сфер социогуманитарного знания - социологии и социальной

\footnotetext{
${ }^{13}$ Пасками (пасочками; южнн-российский диалектизм) в станицах называют куличи.
} 
психологии, экономики, социальной географии, культурной антропологии как основы для политического анализа. В фокусе такого анализа должна быть оценка нематериальных ресурсов развития сельских сообществ и разработка соответствующих их потенциалу политико-управленческих практик.

Важными приоритетами являются изменение укоренившегося в российском общественном сознании отношения к селу и селянам, формирование образа села как источника живой традиции, а селян - как хранителей культурного и природного ландшафта, поддерживающим узнаваемые общезначимые маркеры национальной и региональной идентичности. Опыт таких стран, как Австрия и Великобритания, подтверждает, что позитивное восприятие села в общественном сознании тоже создает невидимые, но значимые стимулы развития.

Существует немало сел, деревень и станиц, сохранивших статус преуспевающих в постсоветский период ${ }^{14}$. Эти истории успеха нужно аккумулировать, внимательно изучать факторы, стимулирующие развитие. Субъекты развития (органы местного самоуправления, социальные группы, гражданские инициативы или отдельные личности), ставшие драйверами роста и социально-экономического благополучия сельских территорий, нуждаются в государственной поддержке - не только финансовой, но и информационной. Важно, что во многих селах, которые в полной мере демонстрируют “истории успеха”, помимо выращивания и переработки аграрной продукции создается и развивается рынок услуг, ориентированный на символические ресурсы сельских поселений. На этом рынке встречаются не только такие распространенные услуги, как аграрный туризм, этнографические комплексы и музеи, экологические тропы, но и набирающие популярность онлайн-фермы, экскурсии по следам литературных и кинематографических героев, мастер-классы для детей и взрослых в местах народных промыслов. Тем самым закладывается основа для благополучия села в новых экономических условиях.

Наличие сформированной локальной идентичности позволяет сельским жителям осознать свои интересы, артикулировать их и искать пути политической институционализации интересов, включения их в общенациональную повестку дня. Не всегда выраженная локальная идентичность является ресурсом развития, и она может иметь ретроспективную темпоральную ориентацию. Но политика развития не может быть успешной без активной позиции селян, формируемой на основе локальной идентичности, без осознания себя как сообщества - субъекта развития территории. Все стратегии развития сельских территорий целесообразно разрабатывать и реализовывать с учетом этих факторов, а документы, раскрывающие стратегии, стоит дополнить разделом “Политика идентичности”. Видение проблемы - шаг к ее решению.

Ситуация Краснодарского края достаточно уникальна, но во многих проявлениях типична. Подходы и инструментарий, использованные в данном проекте, могут быть успешно применены учеными и практиками в других регионах при изучении как сельской, так и городской идентичности. Авторы надеются, что представленное исследование будет полезным для продвижения “сельской” проблематики в поле российской политической науки.

\footnotetext{
${ }^{14}$ Кейс села Средняя Елюзань Пензенской области изучен Л.В. Сагитовой [Сагитова 2012]. Примером динамичного развития с использованием символических ресурсов является село Сеп (Удмуртия), где большую известность получил созданный здесь по инициативе жителей и при поддержке бизнеса (Фонда Потанина) Народный Музей исчезнувших деревень (Народный Музей исчезнувших деревень. URL: https://business.google.com/website/nmid/ (accessed 14.02.2020)).
} 
Проведенное исследование позволило эмпирически обосновать необходимость соединения в анализе политики развития институционального и идентитарного измерений, принципиально важного для понимания ее приоритетов и мотиваций. Осмысление политики идентичности как ресурса развития особенно важно для консолидации сельских сообществ как акторов политики развития. Как показало наше исследование, консолидация местного сообщества происходит здесь на основе сочетания экономических и неэкономических факторов, при том, что общественный дискурс (на политическом уровне в России артикуляция интересов сельских сообществ слаба) во многом определяет актуальные политико-управленческие приоритеты государственной политики.

Наши результаты свидетельствуют о том, что позитивная локальная идентичность населения с перспективной темпоральной ориентацией способствует формированию целого комплекса нематериальных ресурсов, в том числе символических, сетевых, организационно-управленческих и информационнокоммуникативных, а также разделяемых жителями ценностных ориентиров. В его основании находится локальная идентичность, и он может быть эффективно использован для проектирования развития сельских территорий. Современная ориентация государственного управления РФ на достижение национальных и региональных приоритетов на основе проектного подхода открывает новые возможности для формирования и развития сельских территорий с учетом их социально-экономических и культурных особенностей. В условиях актуализации экологических вызовов и важности поддержания баланса между природной и культурной средами обитания человека, что является условием поддержания достойного качества жизни, включенность в политику развития сельских территорий во многом определяет перспективы политической стабильности национальных сообществ, уровень социального благополучия и моральный климат в обществе.

Актуализация локальной идентичности как стратегического ресурса развитии территории будет способствовать переформатированию сложившейся системы политического представительства в РФ. Речь идет о появлении новых или реформировании существующих политических партий, способных аккумулировать и агрегировать потребности села и интересы селян, предлагать инновационные способы решения проблем сельских территорий на основе их ресурсного потенциала.

Изучение политики развития является осевым направлением в осмыслении политической реальности современного мира и перспектив его динамики. Местные сообщества - активно действующие на этом поле акторы. Оценка ресурсов и ограничений их деятельности имеет принципиально важное значение для разработки эффективных управленческих практик и для продвижения моделей ответственного развития, опирающихся на баланс материальных и нематериальных ресурсов. И для реализации политики идентичности, и для брендирования территории, и для продвижения новых, современно мыслящих кадров нужны материальные вложения. Но если экономические стратегии не опираются на социокультурные основания, “цементирующие” сообщество, все инвестиционные проекты будут всего лишь иллюстрацией слогана “Деньги на ветер!”, и развитие сменится деградацией.

Конфликтное перераспределение более 30 полномочий между районными и поселенческими уровнями муниципальных образований, обусловленное скудостью бюджетов низового уровня, препятствует формированию ло- 
кальных сообществ с устойчивой идентичностью. Политические проекты, связанные с еще одним перераспределением полномочий, вряд ли приведут к решению данной проблемы. Позитивной альтернативой может стать развитие межпоселенческого сотрудничества, институциональное закрепление прав сотрудничающих сторон и кооперация усилий соседских территорий для решения общих, типовых проблем.

Мы вИдим ключевую задачу политической науки в формировании публичного дискурса, соответствующего приоритетам развития сельских территорий, в налаживании механизмов обратной связи между экспертами и теми, кто является объектом исследований, в стимулировании вовлеченности местных сельских сообществ и целенаправленном продвижении их интересов в политическую повестку дня.

DOI: $10.17976 / \mathrm{jpps} / 2020.03 .05$

\title{
IDENTITY POLICIES IN RURAL LOCAL COMMUNITY DEVELOPMENT IN RUSSIA
}

\author{
E.V. Morozova ${ }^{1}$, I.V. Miroshnichenko ${ }^{1}$, I.S. Semenenko ${ }^{2}$ \\ ${ }^{1}$ Kuban State University. Krasnodar, Russia \\ ${ }^{2}$ Primakov National Research Institute of World Economy and International Relations (IMEMO), Russian \\ Academy of Sciences. Moscow, Russia
}

MOROZOVA, Elena Vasilievna, Dr. Sci. (Phil.), Professor, Department of Public Policy and Public Administration, Kuban State University, email: morozova_e@inbox.ru; MIROSHNICHENKO, Inna Valerievna, Dr. Sci. (Pol. Sci.), Head of Public Policy and Public Administration Department, Kuban State University, email: mirinna78@mail.ru; SEMENENKO, Irina Stanislavovna, Dr. Sci. (Pol. Sci.), Corresponding Member, Russian Academy of Sciences, Deputy Director, Primakov National Research Institute of World Economy and International Relations, Russian Academy of Sciences, email: semenenko@imemo.ru

Morozova E.V., Miroshnichenko I.V., Semenenko I.S. Identity Policies in Rural Local Community Development in Russia. - Polis. Political Studies. 2020. No. 3. P. 56-77. (In Russ.) https://doi.org/10.17976/jpps/2020.03.05

Acknowledgements. The study was carried out with the financial support of the Russian Foundation for Basic Research and the Expert Institute for Social Studies within the framework of the research project No. 19-011-31356 "Development of Rural Local Communities: The Potential of Identity Politics in the Context of the Heterogeneity of Socio-economic and Socio-cultural Space of a Region”.

Received: 25.12.2019. Accepted: 04.03.2020

\begin{abstract}
The article substantiates the criteria for assessing the role of identity politics and the potential of identity policies in local community development. Identifying this potential is crucial for assessing the prospects of a paradigm shift in development policies in a changing world order. The emergence of new cleavages in contemporary societies - due to rapidly growing digital divides and disparities between territories - calls for a new development agenda for different levels of political governance. Attention to intangible resources and administrative priorities for the development of non-urban territories has been growing in political studies in recent years, particularly, in the context of "rural" studies across different regions of the world. As such, identity politics are considered an intangible resource, and include policies aimed at forming strong local identities to promote community development. This research is based on an empirical study conducted by the authors in Krasnodar Krai in 2019 ( 8 focus-group interviews and 40 expert interviews in 8 rural settlements). Drawing on empirical data several markers of rural local identity were detected and described, and an identity policy matrix relevant for local communities was constructed. The level of involvement by various actors and agencies in the development of rural territories, and the character of the development activities, were the main criteria applied to discern three types of identity policies which the authors describe as reactive, proactive, and active. Their potential in promoting the development of Russian rural territories was determined, taking into account the unique socio-cultural and natural-geographical landscape, the heterogeneity of the socio-economic and sociocultural space of Russian
\end{abstract}


regions, and the variety of institutional models of local community agency present in contemporary rural Russia. The authors advocate the promotion of "rural" (non-urban) studies in political science in Russia.

Keywords: rural local communities, non-urban territories, rural studies, development policy, intangible development resources, local identity, rural identity, identity politics, identity markers, Krasnodar Krai, Russia.

\section{References}

Cruickshank J., Lysgård H.K., Magnussen M.-L. 2009. The Logic of the Construction of Rural Politics: Political Discourses on Rurality in Norway. - Geografiska Annaler. Series B. Human Geography. Vol. 91. No. 1. P. 73-89.

Dymitrow M. 2018. Rural/Urban: Laying Bare the Controversy. - Geographia Polonica. Vol. 91. No. 4. P. 375-397. https://doi.org/10.7163/GPol.0126

Glenn T.J. 1986. Neighborhood and Sense of Community. - Journal of Community Psychology. Vol. 14. No. 4. P. 341-352. https://doi.org/10.1002/1520-6629(198610)14:4<341::AID-JCOP2290140403>3.0.CO;2-0 Handbook of Rural Studies. 2006. Ed. by P. Cloke, T. Marsden, P.H. Mooney. London, Thousand Oaks, CA: SAGE. 528 p. http://dx.doi.org/10.4135/9781848608016

Heller K. 1989.The Return to Community. - American Journal of Community Psychology. Vol. 17. No. 1. P. 1-15. https://doi.org/10.1007/BF00931199

Kotkin J. 2000. The New Geography: How Digital Revolution is Reshaping the American Landscape. New York: Random House. 242 p.

Leach B., Pini B. 2011. Reshaping Gender and Class in Rural Spaces. London, New York: Routledge. 266 p.

Lundgren A.S., Johansson A. 2017. Digital Rurality: Producing the Countryside in Online Struggles for Rural Survival. - Journal of Rural Studies. Vol. 51. No. 1. P. 73-82. https://doi.org/10.1016/j.jrurstud.2017.02.001

McMillan D.W. 1996. Sense of Community. - Journal of Community Psychology. Vol. 24. No. 4. P. 315-325. https://doi.org/10.1002/(SICI) 1520-6629(199610)24:4<315::AID-JCOP2>3.0.CO;2-T

Nartova N.A., Krupets Y.N. 2019. 'It is Hard for Me to Live in the City': Local Identities and Place Attachment among Young Rural Russians. - Monitoring of Public Opinion: Economic and Social Changes. No. 1. P. 342-361. https://doi.org/10.14515/monitoring.2019.1.17

Neal S. 2009. Rural Identities. Ethnicity and Community in the Contemporary English Countryside. Farnham: 76 Ashgate. $170 \mathrm{p}$.

Nilsson B., Lundgren A.S. 2018. "For a Living Countryside": Political Rhetoric about Swedish Rural Areas. European Urban and Regional Studies. Vol. 25. No. 1. P. 72-84. https://doi.org/10.1177/0969776416679216

The New Rural Paradigm: Policies and Governance. 2006. - OECD. Paris. URL: https://www.oecd.org/ $\mathrm{cfe} /$ regional-policy/thenewruralparadigmpoliciesandgovernance.htm (accessed 25.03.2020).

Routledge International Handbook of Rural Studies. 2016. Ed. by M. Schusmith, D.L. Brown. London, New York: Routledge. 698 p.

Svendsen G.L.H. 2004. The Right to Development: Construction of a Non-Agriculturalist Discourse of Rurality in Denmark. - Journal of Rural Studies. Vol. 20. No. 1. P. 79-94. https://doi.org/10.1016/S0743-0167(03)00045-7 Woods M. 2011. Rural. London: Routledge. 340 p.

Filippov Yu.V., Avdeeva T.T. 2000. Osnovy razvitiya mestnogo khozyaistva [Foundations of Local Economy Development]. Moscow: Delo. 264 p. (In Russ.)

Filippov Yu.V., Avdeeva T.T., Lavrova T.G. 2013. Teorii mestnogo ekonmicheskogo razvitiya [Theories of Local Econmic Development]. Moscow: Prospekt. 130 p. (In Russ.)

Halbwachs M. 2005. La Mémoire collective. (Russ. ed.: Halbwachs M. Kollektivnaya i istoricheskaya pamyat'. - Neprikosnovennyi zapas. No. 2. P. 8-27). URL: http://magazines.russ.ru/nz/2005/2/ha2.html (accessed 25.03.2020).

Identichnost: Lichnost, obshchestvo, politika. Entsiklopedicheskoe izdanie [Identity: The Individual, Society, and Politics. An Encyclopedia]. Ed. by I.S. Semenenko. 2017. Moscow: VES MIR. 992 p. (In Russ.)

Lyska A.G. 2013. The Concept of Building a Local Community in the Works of Foreign Scientists. Sociological Studies. No. 7. P. 99-104. (In Russ.)

Malinova O.Yu. 2017. Simvolicheskaya politika [Symbolic Politics]. - Identichnost: Lichnost, obshchestvo, politika. Entsiklopedicheskoe izdanie [Identity: The Individual, Society, and Politics. An Encyclopedia]. Ed. by I.S. Semenenko. Moscow: VES MIR. P. 655-660. (In Russ.)

Malye goroda v sotsial'nom prostranstve Rossii [Small Cities in the Social Space of Russia]. 2019. Ed. by V.V. Markin, M.F. Chernysh. Moscow: FCTAS RAS. 545 p. (In Russ.) https://doi.org/10.19181/ monogr.978-5-89697-323-2.2019

Morozova E.V. 2018. Sel'skaya identichnost': politicheskii rakurs [Rural Identity: A Political Perspective]. - Politika razvitiya, gosudarstvo i mirovoi poryadok. Materialy VIII Vserossiiskogo kongressa 
politologov. Moskva, 6-8 dekabrya 2018goda [Development Policy, State and World Order. Materials of the VIII All-Russian Congress of Political Scientists. Moscow, December 6-8, 2018]. Ed. by O.V. Gaman-Golutvina, L.V. Smorgunov, L.N. Timofeeva. Moscow: Aspect Press. P. 359. (In Russ.)

Nikiforova E. 2013. "Torgovtsy krasotoi": zametki o rebrendinge estonskoi derevni ["Beauty Traders": notes on rebranding of an Estonian village]. - Vdali ot gorodov: Zhizn' postsovetskoi derevni [Far from Cities: Life of the post-Soviet Village]. Ed. by E. Bogdanova, O. Brednikova. Saint Petersburg: Aletheia. P. 144-167. (In Russ.)

Pushkareva G.V. 2017. Simvolicheskie formy konstruirovaniya politicheskoi real'nosti [Symbolic Forms and Construction of Political Reality]. - Simvolicheskaya politika. Vypusk 5. Politika identichnosti. [Symbolic Politics. Vol. 5. Identity Politics]. Moscow: INION RAN. P. 61-80. (In Russ.)

Sagitova L.V. 2012. Traditional and New in Islam: Case Middle Yeluzan. - Sociological Studies. No. 2. P. 104-114. (In Russ.)

Semenenko I.S. 2019a. Horizons of Responsible Development: from Discourse to Governance. - Polis. Political Studies. No. 3. P. 7-26. (In Russ.) https://doi.org/10.17976/jpps/2019.03.02

Semenenko I.S. 2019b. The Rural Local Community in Development Policies in Europe: Discourse and Agency. - South-Russian Journal of Social Sciences. Vol. 20. No. 3. P. 6-27. (In Russ.) https://doi. org/10.31429/26190567-20-3-6-27

Smirnyagin L.V. 2016. Evolyutsiya mesta v khode "proizvodstva prostranstva" [The Evolution of Place in Context of the "Production of Space"]. - Simvolicheskaya politika. Vypusk 4. Sotsial'noe konstruirovanie prostranstva [Symbolic Politics. Vol. 4. Social Construction of Space]. Moscow: INION RAN. P. 84-105. (In Russ.)

Vdali ot gorodov: Zhizn' postsovetskoi derevni [Far from Cities: Life of the post-Soviet Village]. 2013. Ed. by E. Bogdanova, O. Brednikova. Saint Petersburg: Aletheia. 232 p. (In Russ.)

\section{Литература на русском языке}

Вдали от городов: Жизнь постсоветской деревни. 2013. Под ред. Е. Богдановой, О. Бредниковой. СПб: Алетейя. $232 \mathrm{c}$.

Идентичность: Личность, общество, политика. Энциклопедическое издание. 2017. Отв. ред. И.С. Семененко. М.: Весь Мир. 992 с.

Лыска А.Г. 2013. Концепция строительства местного сообщества в работах зарубежных ученых. Социологические исследования. № 7. С. 99-104.

Малинова О.Ю. 2017. Символическая политика. - Идентичность: Личность, общество, политика. Энциклопедическое издание. Отв. ред. И.С. Семененко. М.: Весь Мир. С. 655-660.

Малые города в социальном пространстве России. 2019. Отв. ред. В.В. Маркин, М.Ф. Черныш. М.: ФНИСЦ РАН. 545 c. https://doi.org/10.19181/monogr.978-5-89697-323-2.2019

Морозова Е.В. 2018. Сельская идентичность: политический ракурс. - Политика развития, государство и мировой порядок. Материалы VIII Всероссийского конгресса политологов. Москва, 6-8 декабря 2018 г. Под ред. О.В. Гаман-Голутвиной, Л.В. Сморгунова, Л.Н. Тимофеевой. М.: Аспект Пресс. 359 с.

Никифорова Е. 2013. “Торговцы красотой”: заметки о ребрендинге эстонской деревни. - Вдали от городов: Жизнь постсоветской деревни. Под ред. Е. Богдановой, О. Бредниковой. СПб: Алетейя. С. 144-167.

Пушкарева Г.В. 2017. Символические формы конструирования политической реальности. Символическая политика. Выпуск 5. М.: ИНИОН РАН. С. 61-80.

Сагитова Л.В. 2012. Традиционное и новое в исламе: кейс Средняя Елюзань. - Социологические исследования. № 2. С. 104-114.

Семененко И.С. 2019а. Горизонты ответственного развития: от научного дискурса к политическому управлению. - Полис. Политические исследования. № 3. С. 7-26. https://doi.org/10.17976/ jpps/2019.03.02

Семененко И.С. 2019b. Сельское местное сообщество в фокусе политики развития: научный дискурс и европейские политические реалии. - Южно-российский журнал социальных наук. Т. 20. № 3. C. 6-27. https://doi.org/10.31429/26190567-20-3-6-27

Смирнягин Л.В. 2016. Эволюция места в ходе “производства пространства”. - Символическая политика. Вып. 4. Социальное конструирование пространства. М.: ИНИОН РАН. С. 84-105.

Хальбвакс М. 2005. Коллективная и историческая память. - Неприкосновенный запас. № 2. С. 8-27. URL: http://magazines.russ.ru/nz/2005/2/ha2.html (accessed 25.03.2020).

Филиппов Ю.В., Авдеева Т.Т. 2000. Основы развития местного хозяйства. М.: Дело. 264 с.

Филиппов Ю.В., Авдеева Т.Т., Лаврова Т.Г. 2013. Теории местного экономического развития. М.: Проспект. 130 с. 